Research Article

\title{
Sexually Transmitted Infection in Correlation with Cervical Precancerous Lesion
}

\section{Infeksi Menular Seksual dan Hubungannya dengan Lesi Prakanker Serviks}

\author{
Junita Indarti ${ }^{1}$, Riyan H Kurniawan ${ }^{1}$, Hanny Nilasari ${ }^{2}$ \\ ${ }^{1}$ Department of Obstetrics and Gynecology \\ ${ }^{2}$ Department of Dermatovenereology \\ Faculty of Medicine University of Indonesia/ \\ Dr. Cipto Mangunkusumo Hospital \\ Jakarta
}

\begin{abstract}
Objective: To identify the correlation between sexually transmitted infection and cervical precancerous lesion.

Method: The study design is cross-sectional. Samples were collected by consecutive sampling method until the minimal amount was fulfilled. This study was conducted in the Colposcopy Outpatient Clinic and Cytology Laboratory, Division of Specialistic Gynecology, Department of Obstetrics and Gynecology, Dr. Cipto Mangunkusumo Hospital (RSCM), Jakarta, from September 2008 to March 2009. Laboratory examination for sexually transmitted infection (STI) was performed in Department of Dermatovenereology, RSCM, Jakarta. Patients were grouped into cases and control group. The case group consisted of patients diagnosed with cervical intraepithelial neoplasia (CIN) and the control group consisted of patients without CIN. Sexually transmitted infection was identified and its relationship to CIN was analyzed.
\end{abstract}

Result: We included 130 patients into this study, 25.38\% without CIN and $74.62 \%$ with CIN. We found that one patient can be infected by up to five types of infection at a time. We also discovered a statistically significant relation between CIN 1 and STI ( $\mathrm{p}=0.028)$, CIN 2 and STI ( $\mathrm{p}=0.007)$, and CIN 3 and STI ( $\mathrm{p}=0.013)$.

Conclusion: Based on our study, we discovered a significant relationship between the incidence of STI and CIN.

[Indones J Obstet Gynecol 2015; 1: 51-55]

Keywords: cervical intraepithelial neoplasia, cervical precancerous lesion, sexually transmitted infection

\begin{abstract}
Abstrak
Tujuan: Untuk mengetahui hubungan antara infeksi menular seksual dengan lesi prakanker serviks.

Metode: Desain penelitian ini adalah studi potong-lintang. Pengambilan sampel dilakukan dengan cara consecutive sampling sampai batas sampel minimal terpenuhi. Penelitian dilakukan di Poliklinik Kolposkopi dan Laboratorium Sitologi, Divisi Ginekologi Spesialistik, Departemen Obstetri dan Ginekologi, RSUPN Dr. Cipto Mangunkusumo (RSCM), Jakarta, dari September 2008 hingga Maret 2009. Pemeriksaan laboratorium infeksi menular seksual (IMS) dilakukan di Departemen Kulit dan Kelamin, RSCM, Jakarta. Pasien dikelompokkan menjadi dua kelompok, kelompok kasus, yaitu pasien dengan neoplasia intraepitel serviks (NIS) dan kelompok kontrol, yaitu pasien tanpa NIS. IMS pada setiap kelompok akan diidentifikasi dan dianalisa hubungannya dengan kejadian NIS.
\end{abstract}

Hasil: Kami mengikutsertakan 130 pasien dalam studi ini, 25,38\% tanpa NIS dan 74,62\% dengan NIS. Satu pasien dapat menderita 1 sampai 5 jenis infeksi menular seksual pada saat yang bersamaan. Kami menemukan hubungan yang bermakna antara NIS 1 dengan IMS $(p=0,028)$, NIS 2 dengan IMS $(p=0,007)$, dan NIS 3 dengan IMS $(p=0,013)$.

Kesimpulan: Berdasarkan penelitian kami, kami menemukan hubungan yang bermakna antara insidens IMS dan NIS.

[Maj Obstet Ginekol Indones 2015; 1: 51-55]

Kata kunci: infeksi menular seksual, lesi prakanker serviks, neoplasia intraepitelial serviks

Correspondence: Junita Indarti, Department of Obstetrics and Gynecology, Faculty of Medicine University of Indonesia, dr. Cipto Mangunkusumo Hospital. Jln. Diponegoro no. 71, Central Jakarta, Indonesia. Telephone: 0816970313, E-mail: junita_indarti@yahoo.com

\section{INTRODUCTION}

Cervical cancer is the second most common cancer encountered in women worldwide and is associated with the highest mortality rate among gynecologic cancers. In 2002, approximately 493,000 new cases was diagnosed and $83 \%$ was found in developing countries. ${ }^{1}$ In Indonesia, the prevalence rate of cervical cancer is around 100-190 per 100,000 population. ${ }^{2}$ According to data from 11 pathology centers in Indonesia, cervical cancer ranked first and comprised $23.54 \%$ of all cancers in men and women, or $30.63 \%$ of the ten most common types of cancer in women. ${ }^{3}$ Cervical cancer remains a major problem in Indonesia because most subjects $(62 \%)$ present to the clinic at a late stage.

Cervical cancer is not a condition that occurs suddenly, but may take 5-20 years to develop from carcinoma in situ into invasive cervical cancer. ${ }^{4}$ 
Cervical intraepithelial neoplasia (CIN) demonstrates a disease spectrum ranging from mildly dysplastic cytoplasmic and nuclear changes to those of severe dysplasia. At this stage, there is no invasion through the basement membrane, as opposed to invasive cancer. The severity of a lesion is graded according to the proportion of affected epithelium as measured from the basement membrane upwards.

More than $50 \%$ of women worldwide do not acquire HPV infection in her lifetime, and only 10$20 \%$ of HPV infections become persistent and develop into precancerous lesions or cervical cancer. ${ }^{5}$

Sexually transmitted infection (STI) has been demonstrated to have a relationship with cervical cancer. A variety of microorganisms transmitted through sexual contact have been reported as risk factors for cervical cancer.

There are still few studies on STI and their correlation with cervical precancerous lesion in Indonesia. Thus, the purpose of this study is to evaluate the pattern of sexually transmitted infections and which infections represent the strongest risk in subjects with cervical precancerous lesions.

\section{METHOD}

Our research design was cross-sectional. This research has received approval from The Committee of Medical Research Ethics of the Faculty of Medicine, University of Indonesia and all subjects signed an informed consent.

A total of 130 subjects who came to the Colposcopy Clinic, Department of Obstetrics and Gynecology, Dr. Cipto Mangunkusumo Hospital (RSCM), Jakarta, met the inclusion criteria of the research. Inclusion criteria for case subjects include age 18-50 years old, have had previous sexual intercourse, and diagnosed with CIN from histopathological examination. Abnormal cells confined to the lower third of the squamous epithelium are referred to as mild dysplasia or CIN 1, extending into the middle third as moderate dysplasia or CIN 2, and into the upper third as severe dysplasia or CIN 3. Inclusion criteria for controls were age 18-50 years old, have had previous sexual intercourse, and not diagnosed with CIN from histopathological examination. The exclusion criteria for both groups was current pregnancy.
All subjects had been selected at an early stage through a Pap test and histopathological examination of the subject. All subjects underwent laboratory examination for STI. Laboratory tests were conducted at the Department of Dermatovenereology Laboratory, Dr. Cipto Mangunkusumo Hospital, Jakarta.

Nonspecific cervicitis is diagnosed by laboratory examination of endocervical discharge using Gram staining, where polymorphonuclear cell count is greater than 30 per visual field with absence of gram-negative intracellular diplococcus, Trichomonas vaginalis, or Candida albicans yeast element. Neisseria gonorrhea diagnosis is confirmed by laboratory examination of vaginal discharge using Gram staining, yielding positive result for Gramnegative diplococci, intra and extra-PMN. Treponema pallidum infection is diagnosed by reactive serologic test for Syphillis (STS) using VDRL-TPHA examination. Trichomonas vaginalis is diagnosed by microscopic examination of wet preparation and visualization of actively moving parasites. Candida albicans diagnosis is obtained through laboratory examination of vaginal swabs using KOH 10\% solution and visualization of visible yeast cells, hyphae blastospores or pseudohyphae. Diagnosis of bacterial vaginosis is determined by examination of wet preparation of vaginal discharge and presence of $>20 \%$ of clue cells.

Statistic analysis was performed using Stata version 9.2. Univariate analysis was used to determine distribution of demographic profiles, risk factor, and STI; while bivariate analysis was used to determine distribution of independent variable frequency in correlation with sexually transitted diseases, as presented by the Odds Ratio (OR).

Categorization was made based on cut-off-point on demographic factors (age, education level, and parity) and risk factors (sexual partners, first sexual intercourse, oral contraception, smoking, and history of STI). Before scoring, data transformation was performed due to incomplete data.

\section{RESULTS}

A total of 130 subjects who met the inclusion criteria were included in the research. One hundred and four subjects were included in the case group, consisting of 33 subjects with CIN 1, 41 subjects with CIN 2, and 30 subjects with CIN 3. Meanwhile, a total of 26 subjects were recruited as controls. 
Demographic characteristics obtained from both case and control groups were comparable. The average age for CIN groups is 34.65 years old, while the average age for CIN 1; CIN 2; CIN 3 were 32.03 years old; 32.49 years old; and 32.63 years old, respectively. There was no significant difference in terms of age between the three groups. In terms of education level, more than three-quarters of patients with CIN received formal education for less than 13 years. The average parity is 1.72 for all the groups.

All of the subjects underwent laboratory examination for STI. From 130 subjects, 38 (29.33\%) subjects were diagnosed with STI and 92 (70.77\%) without STI.

Table 1 shows the distribution of STI in our subjects. We can see that approximately a third of subjects suffer from single-organism STI, while the remaining subjects had up to five concurrent infections.
Table 2 shows that subjects who have STI are at higher risk for the occurrence of CIN compared to subjects who do not have STI. Odds ratio (OR) of CIN 1, CIN 2, and CIN 3 compare to no CIN and the p-value is respectively 10.87 (95\% CI 1.29-91.67, $\mathrm{p}=0.028) ; 17.71$ (95\% CI 2.18-143.62, $\mathrm{p}=0.007)$ and 14.47 (95\% CI 1.72-122.07, $\mathrm{p}=0.014$ ).

On examination for nonspecific cervicitis, 113 were categorized as not infected and 17 subjects categorized as infected. Microscopic examination to diagnose gonorrhea, found 5 subjects to be infected by Neisseria gonorrhea. Examination of VDRL and TPHA serology identified 20 subjects as suffering from syphilis. From wet mount preparation for Trichomonas vaginalis examination, 10 subjects were categorized as infected subjects. Furthermore, 22 subjects were found to be positive on examination for Candida or yeast component. Finally, on examination for bacterial vaginosis, clue cells were visualized in microscopic examination of 23 subjects.

Table 1. Distribution of Sexually Transmitted Infection in All Subjects.

\begin{tabular}{|c|c|c|}
\hline \multirow{2}{*}{ Characteristics of STI } & \multicolumn{2}{|c|}{$n=38(29.33 \%)$} \\
\hline & $\mathbf{n}$ & $(\%)$ \\
\hline Nonspecific cervicitis & 1 & 0.77 \\
\hline Nonspecific cervicitis + B. vaginosis & 1 & 0.77 \\
\hline Nonspecific cervicitis + C. albicans & 1 & 0.77 \\
\hline Nonspecific cervicitis $+\mathrm{N}$. gonorrhea $+\mathrm{T}$. vaginalis & 1 & 0.77 \\
\hline Nonspecific cervicitis + STS reactive + C. albicans & 2 & 1.54 \\
\hline Nonspecific cervicitis + C. albicans + B. vaginosis & 3 & 2.31 \\
\hline Nonspecific cervicitis + N. gonorrhea + T. vaginalis + C. albicans & 1 & 0.77 \\
\hline Nonspecific cervicitis + STS reactive + C. albicans + B. vaginosis & 3 & 2.31 \\
\hline Nonspecific cervicitis + N. gonorrhea + T. vaginalis + C. albicans & 1 & 0.77 \\
\hline Nonspecific cervicitis + STS reactive + C. albicans + B. vaginosis & 3 & 2.31 \\
\hline Nonspecific cervicitis + STS reactive + C. albicans + B. vaginosis & 1 & 0.77 \\
\hline Nonspecific cervicitis + N. gonorrhea + STS reactive + T. vaginalis + C. albicans & 1 & 0.77 \\
\hline Nonspecific cervicitis + STS reactive $+\mathrm{T}$. vaginalis $+\mathrm{C}$. albicans $+\mathrm{B}$. vaginosis & 1 & 0.77 \\
\hline STS reactive & 5 & 3.85 \\
\hline STS reactive + C. albicans & 1 & 0.77 \\
\hline STS reactive $+\mathrm{T}$. vaginalis $+\mathrm{B}$. vaginosis & 1 & 0.77 \\
\hline STS reactive $+\mathrm{T}$. vaginalis $+\mathrm{C}$. albicans & 1 & 0.77 \\
\hline STS reactive $+\mathrm{C}$. albicans $+\mathrm{B}$. vaginosis & 3 & 2.31 \\
\hline C. albicans & 2 & 1.54 \\
\hline C. albicans + B. vaginosis & 2 & 1.54 \\
\hline B. vaginosis & 3 & 2.31 \\
\hline N. gonorrhea + STS reactive $+\mathrm{C}$. albicans + B. vaginosis & 1 & 0.77 \\
\hline TOTAL & 38 & 29.33 \\
\hline
\end{tabular}


Table 2. CIN Occurrence According to Characteristics of STI.

\begin{tabular}{lccccccc}
\hline \hline $\begin{array}{c}\text { Presence } \\
\text { of STI }\end{array}$ & $\begin{array}{c}\text { Non CIN } \\
\mathbf{n}(\%)\end{array}$ & $\begin{array}{c}\text { CIN 1 } \\
\mathbf{n}(\%)\end{array}$ & $\begin{array}{c}\text { OR (95\%CI)* } \\
\text { p-value }\end{array}$ & $\begin{array}{c}\text { CIN 2 } \\
\mathbf{n}(\%)\end{array}$ & $\begin{array}{c}\text { OR (95\%CI)* } \\
\text { p-value }\end{array}$ & $\begin{array}{c}\text { CIN 3 } \\
\text { n(\%) }\end{array}$ & $\begin{array}{c}\text { OR (95\%CI)* } \\
\text { p-value }\end{array}$ \\
\hline Absent & $23(69.7)$ & $24(58.54)$ & 1 & $19(63.33)$ & 1 & $26(100)$ & 1 \\
Present & $10(30.3)$ & $17(41.46)$ & $\begin{array}{c}11.29-91.67) \\
\text { p=0.028 }\end{array}$ & $11(36.37)$ & $\begin{array}{c}(2.18-143.62) \\
\text { p=0.007 }\end{array}$ & $\begin{array}{c}0(0.00) \\
(1.72-122.07) \\
p=0.013\end{array}$ \\
\hline \hline
\end{tabular}

${ }^{*}$ chi-square

The occurrence of CIN according to the type of STI is presented in Table 3. Patients with nonspecific cervicitis have a risk of developing CIN 4.89 times more likely than those with Neisseria gonorrhea (95\% CI 0.62-38.53, p-value=0.027). Candida albicans infection has 6.71 times the risk of developing CIN, compared with Gonorrhea infection, although the p-value was shown to be significant, the 95\% CI was 0.86-52.28. Furthermore, CIN was 6.71 times more likely to develop in patients with bacterial vaginitis or BV (95\% CI 0.86-52.28, pvalue $=0.039$ ). Meanwhile, the odds of patients who were STS reactive or found to be infected with Trichomonas vaginalis to develop CIN was higher compared to patients infected with Neisseria gonorrhea but the p-value was 0.068 and 0.100 , respectively.

\section{DISCUSSION}

Various microorganisms have been reported to be associated with the occurrence of cervical cancer, for example Chlamydia trachomatis and Neisseria gonorrhea. ${ }^{6,7}$

In a study by Schiff et $\mathrm{al}^{8}$ the odds of Chlamydia trachomatis, genital herpes, Trichomonas vaginalis, gonorrhoea, and genital warts infection in CIN 2 and CIN 3 patients were $2.2,0.6,1.6,3.0$, and 1.4 consecutively. In our study, we found a slightly different case, where the odds of Chlamydia trachomatis infection, Trichomonas vaginalis, gonorrhoea, and genital warts in relation with the occurrence of CIN were 4.89: 2.65: 1; and 0,24. This can be caused by the different pattern of STI in our country.

Engberts et $\mathrm{al}^{9}$ found Candida albicans in low grade squamous intraepithelial lesion (LSIL) with an OR of 1.85 (95\% CI 1.28-2.67) and in high grade squamous intraepithelial lesion (HSIL) with an OR of 2 (95\% CI 1.31-3.05). Another study by Klomp et $\mathrm{al}^{10}$ stated that the Gardnerella vaginalis had a higher odds for CIN as much as 10.3 times higher (95\% CI 6.6-16.1). In our study, we found that the odds of CIN in patients infected with Gardnerella vaginalis was 6.71 (95\% CI 0.86-52.28). Almost $30 \%$ of all subjects suffered from STI caused by Chlamydia trachomatis, Trichomonas vaginalis, Neisseria gonorrhea, Treponema pallidum, and Candida albicans, as well as bacterial vaginosis, either as a single infection or coinfection. This result implies that health providers should inform patients with STI of the higher risk to develop cervival pre-cancerous lesion.

Trichomonas vaginalis was reported to have higher odds to develop CIN 2 / CIN 3 as high as

Table 3. Occurrence of CIN According to STIs.

\begin{tabular}{lccc}
\hline \hline & OR & $\mathbf{9 5 \%}$ CI & p-value \\
\hline Nonspecific cervicitis & 4.89 & $0.62-38.53$ & 0.027 \\
Neissera gonorrhea & 1 & $0.11-9.34$ & 1 \\
STS reaction & 5.59 & $0.71-43.83$ & 0.068 \\
HSV & 0.24 & $0.01-4.02$ & 0.616 \\
Trichomonas vaginalis & 2.65 & $0.32-21.7$ & 0.100 \\
Candida albicans & 6.71 & $0.86-52.28$ & 0.010 \\
Bacterial vaginosis & 6.71 & $0.86-52.28$ & 0.039 \\
\hline \hline
\end{tabular}


1.6 times $^{11}$, or 3.3 times increase of the relative risk for cervical cancer. ${ }^{11}$ Trichomonas produce nitrosamines, possessing cytotoxic effects, which may damage the cell membrane of the cervix, thus facilitating entrance of HPV infection. Nitrosamines are also known to be carcinogenic and mutagenic agents.

A study demonstrated lack of coinfection between Human Papillomavirus and Chlamydia trachomatis in carcinoma in-situ and invasive adenocarcinoma of the cervix. The role of Chlamydia trachomatis as a carcinogenic cofactor may be restricted to cervical squamous cell carcinomas. ${ }^{12}$

The presence of genital coinfections have an important role in cell proliferation associated with HPV. ${ }^{11}$ Interactions that may occur may involve viruses, cells, and exogenous agents. Exogenous agents may cause initiation of carcinogenesis transformation by HPV DNA amplification or mutation in cells. Candida albicans is the opportunistic fungi that is a potential source of mutagenic stimulus. As elaborated by Voog et al $^{13}$, Candida infections may activate latent HPV infection.

\section{CONCLUSION}

In summary, we discovered a correlation between STIs and the occurrence of precancerous cervical lesions in our study. We also found that Candida albicans and Gardnerella vaginalis has the highest odds to develop CIN.

\section{ACKNOWLEDGEMENTS}

Risbin Iptekdok, Ministry of Health Republic of Indonesia who has helped in funding this research.

\section{REFERENCES}

1. Population Reference Bureau and Alliance for Cervical Cancer Prevention. Preventing Cervical Cancer Worldwide. Seattle: Population Reference Bureau; 2004: 1-24.

2. Tjindarbumi D, Mangunkusumo R. Cancer in Indonesia, present and future. Jpn J Clin Oncol 2002; 32 (Suppl 1): 17-21.

3. Cornain S, Rashid R, Nasar IM, et al. Program kerjasama penelitian dan registrasi kanker. Jakarta: Makalah-makalah Rapat Kerja Nasional YKI; 1992.

4. Wright Jr TC, Cox JT, Massad LS, et al. 2001 Consensus guidelines for the management of women with cervical cytological abnormalities. JAMA 2002; 287(16): 2120-9.

5. Miller AB, Knight J, Narod S. The natural history of cancer of the cervix and the implications for screening policy. In: Miller AB, Chamberlain J, Day NE, et al (eds). Cancer Screening (UICC) Cambridge: Cambridge University Press; 1991: 141-51.

6. Hawes SE, Kiviat NB. Are genital infections and inflammation cofactors in the pathogenesis of invasive cervical cancer? J Natl Cancer Inst 2002; 94: 1592-3.

7. Platz-Christensen JJ, Sundstorm E, Larsson PG. Bacterial vaginosis and cervical neoplasia. Acta Obstet Gynecol Scand 1994; 73: 586-8.

8. Schiff M, Becker TM, Masuk M. Risk factors for cervical intraepithelial neoplasia in southwestern American Indian women. Am J Epidemiol 2000; 152: 716-26.

9. Engberts MK, Verbruggen BS, Boon ME, et al. Candida and dysbacteriosis: a cytologic, population-based study of 100,605 asymptomatic women concerning cervical carcinogenesis. Cancer. 2007; 111(5): 269-74.

10. Klomp JM, Boon ME, Van Haaften M, et al. Cytologically diagnosed Gardnerella vaginalis infection and cervical (pre) neoplasia as established in population-based cervical screening. AJOG 2008; 199(5): 480.e1-5.

11. Samoff E, Koumans EH, Markowitz LE, et al. Asociation of Chlamydia trachomatis with persistence of high-risk types of Human Papillomavirus in a cohort of female adolescents. Am J Epidemiol 2005; 162: 668-75.

12. Zhang ZF, Graham S, Yu SZ, et al. Trichomonas vaginalis and cervical cancer. A prospective study in China. Ann Epidemiol 1995; 5: 325-32.

13. Voog E, Bolmstedt A, Olofsson S, et al. Human papilloma virus infection among women attending an STD clinic correlated to reason for attending, presence of clinical signs, concomitant infections and abnormal cytology. Acta Derm Venereol 1995; 75: 75-8. 